\title{
The Development of Contextual Teaching and Learning-Based Comic as a Learning Media for Ele- mentary School Students
}

\author{
A. Rosyida, Mustaji, \& W. T. Subroto \\ Universitas Negeri Surabaya, Surabaya, Indonesia
}

\begin{abstract}
The research aimed at developing and testing the validity, practicality, as well as the effectiveness of learning a learning media in the form of comic based on Contextual Teaching and Learning (CTL) on Social studies. Observation model and development model (R\&D) of Borg and Gall used were the research. The result of this research showed that the CTL-based comic is a reasonable, practical and effective media. The use of CTL-based comic gives influence to the learning outcomes of the students. It could be seen through the result of the t-test from the try-out which showed that $t_{\text {count }}$ is $2.55>$ from $t_{\text {table }} 2.903$. The use of CTL-based comic as a learning media also got good response from the students with percentage $\mathbf{9 0 . 5 \%}$. Therefore, it could be concluded that CTL-based comic was reasonable, practical and effective to improve the learning outcomes on Social studies lesson of the third-grade students in Elementary School.
\end{abstract}

Keywords - Comic Media, Contextual Teaching and Learning

\section{INTRODUCTION}

Learning activity is a series of activities done to reach the learning aim. The important components in a learning activity are teacher and student. A thing which needs to be concerned in order to meet the learning aim is the ability of the teacher in mastering the material and increasing student's motivation. One of the ways that can be used to get those things is using learning media. The use of media included in the learning aims is to ease the teachers in delivering the material to the students, therefore the learning activity can be more meaningful. According to Hamalik (in Arsyad, 2006, p. 13) the use of media in a learning process can raise new willingness and interest, motivation and learning stimulus, and even bring psychological influence to children. In selecting a learning media, student's characteristic should be considered [2] as what Piaget said (in Budiarti dan Haryanto, 2016) that students in the age of 7-12 years are in the concrete operational stage [3]. Therefore, the right media selection can improve the quality of learning process to be more effective. Social study is one of the main subjects in elementary school. Through social studies, students are prepared to be a part of social society by learning the social phenomena around them [8].
Considering the importance of learning economy as part of social studies, teacher needs to pay attention on the learning process. Teachers are expected to be able create fun learning situation in order that the material explained can be wellunderstood by the students. It can be done by using Contextual Teaching Learning (CTL) approach in which CTL will make the students understand the material explained easier since the material is connected to the students' lives as what have been stated by O'Sullivan (2005) that a learning process using CTL will improve the input quality [6].

Generally, in the process of teaching and learning of social studies, the students learned that trading is still done traditionally. The teacher explained it through lecturing method using only a textbook as source. Besides, the teacher still found it difficult to choose the right media to deliver social study material about trading. The teachers depended only on pictures in the textbook to help them in delivering the lesson, whereas the pictures in the book were less interesting since they did not have bright colors on them and a bit boring. That condition made the learning process became teacher-centered and the learning situation was monotonous, uninteresting, and boring. As the result, the students' motivation and interest to study were getting lower so that the learning outcomes achieved were less than the minimum standard score. Such situation needed to be considered by teachers of third grade of Elementary school since creating change in learning activity was needed in order to get the students' attention and improve their enthusiasm so that the learning outcomes achieved could increase.

Based on the problem above, a learning media that can raise the students' learning motivation and ease them in understanding material explained was needed. As stated Briggs (in Sadiman et al., 2010, p. 6) that media is every physical instrument that offers message and stimulates students to learn [7]. The material delivery of social studies on trading should use more interesting and fun activities for the students. Thirdgrade students of elementary school like colorful pictures as 
they find in illustration in comic. Scott McCloud (in Cimermanová, 2015) describes that comic is juxtaposed pictorial and other images in deliberately constructed in sequence to convey information and/or to produce aesthetic response from the readers [4].

In addition, by connecting the lesson with the environment around, it will help students in understand the material. One of the media that can be applied is CTL-based comic. As a learning media, it will help students to learn easier by reading the CTL-based comic rather than reading the textbook with less pictures and colors. By reading comic based on CTL, students will easily understand the trading activity around them as well as the places for trading activity, history of trading, and the advantages of it. The students will understand more on what they see compared to when they only listen to the teacher's explanation. From the description above, it can be concluded that CTL-based comic can be developed to deliver lesson about trading activity at school and at home for the third-grade students of elementary school.

\section{METHOD}

This research is a developmental research since it created a product that was comic as a learning media based on Contextual Teaching and Learning (CTL) on social studies for the third-grade of elementary school students. Sukmadinata (2011, p. 164) explains that research and development (R\&D) is a process or a set of steps to develop a new product or to complete an existing product which can be accounted for teaching and learning process [9].

The development model used in developing this CTLbased comic was R\&D model of Borg and Gall which was adapted by Dick and Carey (Borg and Gall, 2003, p. 573). This model was chosen because Borg and Gall research and development model has steps in developing a product, so the product resulted can be justified and reasonable to be used. The procedure of Borg and Gall development model included assessing needs to identify goal(s), conducting instructional analysis, analyzing the learners and the contents, writing performance objective, developing assessment instruments, developing instructional strategy, developing the media and selecting the instructional materials, designing the media and conducting formative evaluation of instruction, revising the instruction, design and conducting summative evaluation. Based on the steps of Borg and Gall development model, this research only reached up to the ninth stage which is revising product.

According to Borg and Gall development model, product development of CTL-based comic has been previously tested for validation by the experts who were are media expert and material expert. [10] After passing the validation test, then there was personal try out to three students of the third-grade of elementary school students. In this personal try out, every student filled a questionnaire to evaluate the advisability of the media, CTL-based comic. The result of the personal try out would be used as the orientation to do improvement on product. Next, there was a small group for the second try out. This try out involved twelve students of the third grade of elementary school. In this small group trial, every student filled a questionnaire of media advisability. The result was used as the orientation to do product improvement and, later on, to do the field try out. This field try out involved two classes of third grade students in SDI Arrisalah Ponorogo.

The instruments to collect the data used in this research were interview, documentation, observation sheet, questionnaire, learning result test. The advisability analysis of the CTL-based comic was done through the validation sheet which used Likert scale. The validation result was then changed into percentage and classified into some interpretation category. The practicality analysis of the CTL-based comic was done through observation sheet on the learning process and student's activity, while the practicality of the media was based on CTL questionnaire. The result of the observation sheet was later changed into percentage classified into some interpretation category. Next, the effectiveness analysis of the CTLbased comic could be seen through the test of student's learning outcomes. The test took several steps: (1) validity test by the expert (lecturer) and trial to the students by using correlation formula of product moment, (2) testing the reliability of the students' learning outcomes through spearman brown formula, (3) normality test through Chi square, (4) homogeneity test through variant formula, and (5) t-test for the try out through nonequivalent control group design.

\section{RESULTS AND DISCUSSION}

The result of the advisability of the CTL-based comic try out was gotten from the validation sheet and media advisability questionnaire filled by the students. The components which were validated included comic media, learning equipment and experiment instrument. Meanwhile, the media advisability questionnaire was given at personal and small group try out. The result of validation sheet from the validator were:

TABLE I. VALIDATION RESULT

\begin{tabular}{|l|l|l|}
\hline \multicolumn{1}{|c|}{ Validation Sheet } & \multicolumn{1}{|c|}{ Percentage } & \multicolumn{1}{|c|}{ Category } \\
\hline Comic Media (media expert) & $92,65 \%$ & Revision \\
\hline Comic Media (media expert) & $97,06 \%$ & $\begin{array}{l}\text { Advisable to use } \\
\text { with no revision }\end{array}$ \\
\hline $\begin{array}{l}\text { Comic Media (material ex- } \\
\text { pert) }\end{array}$ & $87,05 \%$ & $\begin{array}{l}\text { Advisable to use } \\
\text { with no revision }\end{array}$ \\
\hline Syllabus & $100 \%$ & $\begin{array}{l}\text { Advisable to use } \\
\text { with no revision }\end{array}$ \\
\hline Lesson Plan (RPP) & $89,28 \%$ & $\begin{array}{l}\text { Advisable to use } \\
\text { with revision }\end{array}$ \\
\hline
\end{tabular}




\begin{tabular}{|l|l|l|}
\hline \multicolumn{1}{|c|}{ Validation Sheet } & Percentage & \multicolumn{1}{c|}{ Category } \\
\hline Worksheet (LKS) & $100 \%$ & $\begin{array}{l}\text { Advisable to use } \\
\text { with no revision }\end{array}$ \\
\hline Learning Outcome Test & $75 \%$ & $\begin{array}{l}\text { Advisable to use } \\
\text { with revision }\end{array}$ \\
\hline Questionnaire & $95,8 \%$ & $\begin{array}{l}\text { Advisable to use } \\
\text { with no revision }\end{array}$ \\
\hline $\begin{array}{l}\text { Observation sheet of learning } \\
\text { process }\end{array}$ & $87,05 \%$ & $\begin{array}{l}\text { Advisable to use } \\
\text { with no revision }\end{array}$ \\
\hline $\begin{array}{l}\text { observation sheet of student's } \\
\text { activity }\end{array}$ & $91,75 \%$ & $\begin{array}{l}\text { Advisable to use } \\
\text { with no revision }\end{array}$ \\
\hline
\end{tabular}

TABLE II. The Result of Media AdVISABILITy QuestionNAIRE

\begin{tabular}{|l|l|l|l|l|}
\hline \multicolumn{1}{|c|}{ Trial } & $\begin{array}{c}\text { Number } \\
\text { of stu- } \\
\text { dents }\end{array}$ & $\begin{array}{c}\text { Score } \\
\text { achieved }\end{array}$ & $\%$ & Interpretation \\
\hline $\begin{array}{l}\text { Personal Try } \\
\text { out }\end{array}$ & 3 & 71 & 84,52 & $\begin{array}{l}\text { Very well with } \\
\text { revision }\end{array}$ \\
\hline $\begin{array}{l}\text { Small Group } \\
\text { Try out }\end{array}$ & 12 & 326 & 97,02 & Very well \\
\hline
\end{tabular}

Based on validation sheet evaluated, it was stated that the comic, learning kit and instrument were reasonable to be used in learning process. Meanwhile, the result of questionnaire response for comic was advisable to use.

The result of student's questionnaire response stated that the CTL-based comic was reasonable according to the percentage on personal and small group try out.

The practicality of the CTL-based comic could be seen through the observation sheet of learning process, student's activity and practicality shown in the questionnaire filled by four teachers of the third grade of elementary school. The percentage of learning process was

TABLE III. THE OBSERVATION RESULT OF LEARNING PROCESS

\begin{tabular}{|c|c|l|l|l|}
\hline \multicolumn{2}{|c|}{ Observer } & \multirow{2}{*}{ Quantity } & Percentage & Category \\
\cline { 1 - 2 } O1 & O1 & & & \\
\hline 27 & 31 & 58 & 90,62 & Very well \\
\hline
\end{tabular}

Based on the data above, it could be concluded that the learning process by using comic media based on CTL was very well-conducted. The following is the student's activity during the learning process can be seen as:

TABLE IV. OBSERVATION RESULT OF STUDENT'S ACTIVITY

\begin{tabular}{|l|l|l|l|l|}
\hline \multicolumn{2}{|c|}{ Observer } & \multirow{2}{*}{ Quantity } & Percentage & Category \\
\cline { 1 - 2 } O1 & O1 & & & \\
\hline 20 & 22 & 42 & 87,5 & Very well \\
\hline
\end{tabular}

According to the table above, then it can be concluded that the student's activity during the learning process by using CTL-based comic belonged into very well category. The result of the practicality of the media taken from the questionnaire could be seen in this table.

TABLE V. The Result OF MEdia Practicality QUESTIONNAIRE

\begin{tabular}{|c|c|c|c|c|c|}
\hline \multicolumn{4}{|c|}{ Respondents } & \multirow[t]{2}{*}{ Quantity } & \multirow[t]{2}{*}{ Category } \\
\hline 1 & 2 & 3 & 4 & & \\
\hline 46 & 52 & 45 & 45 & 188 & Very well \\
\hline \multicolumn{4}{|c|}{ Percentage } & $83,9 \%$ & \\
\hline
\end{tabular}

Table $\mathrm{V}$ shows that CTL-based media was categorized very well or practical to be used in the learning process.

The effectiveness of comic media was known as the result of student's leaning test. Before it was used in the experiment, the questions of student's learning test were validated earlier by the expert (lecturer). After that, it was tested to 15 students and counted through correlation formula of product moment, with criteria that a question was considered valid if count $>$ table, is 0,514 . The validation result can be seen in the following table.

TABLE VI. THE RESULT OF QUESTIONS IN VALIDATION INSTRUMENTS

\begin{tabular}{|l|l|}
\hline \multicolumn{1}{|c|}{ Valid question } & \multicolumn{1}{|c|}{ Invalid question } \\
\hline $1,2,4,9,14,15,20,22,24,26$, & $3,5,6,7,8,10,11,12,13,16$, \\
$29,30,32,37,40,41,45,46,48$, & $17,18,19,21,23,25,27,28,31$, \\
49,50 & $33,34,35,36,38,39,42,43,44$, \\
& 47 \\
\hline
\end{tabular}

From those 21 valid questions, 20 questions were taken to be used as test instrument for learning result. After the validation test, there was reliability trial done using spearman brown formula. The result showed that question reliability was 0,926 . Referring to the reliability interpretation based on Guilford, the test can be concluded as having very high reliability.

The questions which had been tested in terms of the validity and reliability, would be used for the pretest and posttest questions in experiment and control class when doing the field try out. The result of the pretest and posttest would be tested by t-test to know the effectiveness of the CTL-based comic. However, before it was tested using t-test, the result of the pretest and posttest went for normality test by using chi-square formula. The result of pretest and posttest normality were:

TABLE VII. THE RESULt OF NORMALITY TEST

\begin{tabular}{|l|l|l|c|}
\hline Normality test & \multicolumn{1}{|c|}{ X count } & X Table & Category \\
\hline $\begin{array}{l}\text { Pretest experi- } \\
\text { ment }\end{array}$ & 1,956 & 9,49 & Data is distributed normally \\
\hline Pretest control & 2,616 & 9,49 & Data is distributed normally \\
\hline $\begin{array}{l}\text { Posttest exper- } \\
\text { iment }\end{array}$ & 2,085 & 9,49 & Data is distributed normally \\
\hline Posttest control & 2,713 & 9,49 & Data is distributed normally \\
\hline
\end{tabular}


After doing the normality test, the next step was doing homogeneity test to know whether both classes were homogenous or not. Homogeneity test was done by doing various formula. The sample was considered homogenous if the score is $\mathrm{Fh}<\mathrm{Ft}$, with $\mathrm{F}_{\mathrm{t}}$ is 2,15 . Here was the result of the pretest and posttest of homogeneity test.

TABLE VIII. THE RESULT OF HOMOGENEITY TEST

\begin{tabular}{|l|l|l|l|}
\hline \multicolumn{1}{|c|}{ Homogeneity test } & \multicolumn{1}{c|}{ F count } & F Table & Category \\
\hline Pretest & 2,03 & 2,15 & Homogenous \\
\hline Posttest & 2,13 & 2,15 & Homogenous \\
\hline
\end{tabular}

After knowing that the data distributed in both classes were normal and homogenous, the next step was doing t-test try out with the criteria used was $\mathrm{H}_{\mathrm{o}}$ accepted if count $<\mathrm{t}_{\text {able }}$.

The t-test try out was done through the following formula [1]:

$$
t-\frac{\bar{x}_{1}-\bar{x}_{2}}{\sqrt{\frac{S D x_{1}^{2}}{N_{1}-1}+\frac{S D x_{2}^{2}}{N_{2}-1}}}
$$

The questions of the learning process test were used as the questions on pretest and posttest for experiment and control class on the field try out for the third-grade students of SDI Arrisalah Ponorogo. Class III A was used as the control class, while class III $\mathrm{C}$ was the experimental class. The field try out was done using nonequivalent pretest-posttest group design technique. To know about the effectiveness of CTL-based comic as a learning media, $t$-test try out was used. Based on ttest trial, it was found that the result was 2,55 with the $t_{\text {able }}$ for df 19 was 2,09. From the result, it could be inferred that 2,55 $\geq 2,093$, so it was concluded that $\mathrm{H}_{\mathrm{o}}$ was denied and $\mathrm{H}_{\mathrm{a}}$ was accepted. Therefore, the learning process using CTL-based comic was effective to improve student's learning outcomes that had been proven with the significant difference of the learning outcomes between the experiment and control classes.

\section{CONCLUSION}

Based on the experiment result and discussion, it could be concluded that: (1) The CTL-based comic was reasonable to be used in social studies lesson dealing with trading activity for third-grade students of elementary school. (2) In addition, CTL-based comic was practical to be used in social studies lesson dealing with trading activity for third-grade students of elementary school. Those conclusions were based on the percentage calculation of the result on observing the learning process, student's activity, and comic media practicality questionnaires. (3) Moreover, the CTL-based comic was effective to to be used in social studies lesson dealing with trading activity for third-grade students of elementary school. It was based on the result of t-test trial, in which the score of count $>t_{\text {able, was }}$ 2,55>2,093. Based on it, $\mathrm{H}_{\mathrm{o}}$ was denied and $\mathrm{H}_{\mathrm{a}}$ was accepted. Therefore, it could be concluded that the learning process using comic media based on CTL was effective to improve the students' learning outcomes because as there was a significant difference of learning outcomes between the students in the experimental and control classes.

\section{REFERENCES}

[1] Arikunto, Suharsimi, Prosedur Penelitian Suatu Pendekatan Praktik, Jakarta: PT. Rineka Cipta, 2010.

[2] A. Arsyad, Media Pembelajaran, Jakarta: Rajagrafindo Persada, 2014.

[3] Budiarti, Wahyu Nuning \& Haryanto, "Pengembangan Media Komik Untuk Meningkatkan Motivasi Belajar dan Keterampilan Membaca Pemahaman Siswa Kelas IV," Jurnal Prima Edukasia, vol. 4, no. 2, pp. 233-242, 2016.

[4] I. Cimermanova, Using Comics With Novice EFL Readers To Develop Reading Literacy, Procedia Social and Behavioral Science, 174, 2452 2459, 2015 .

[5] Gall, D. Meredith Joyce, P Gall, \& Walter R Borg. Educational Research. United States: Pearson Education, Icn. 2003.

[6] M. O'Sullivan, "Lesson Observation And Quality In Primary Education As Contextual Teaching And Learning Processes," International Journal of Educational Development, vol. 26, pp. 246-260, 2005.

[7] Sadiman, S. Arief, R. Rahardjo, Haryono, Anung, dan Rahardjito, Media Pendidikan, Jakarta: Rajagrafindo Persada, 2010.

[8] Subroto, Waspodo Tcipto \& Suhanadji, Pengetahuan Dasar Ilmu-Ilmu Sosial Geografi, Sejarah, Ekonomi, Politik, Sosiologi \& Antropologi, Surabaya: Unesa University Press, 2005

[9] N.S. Sukmadinata, Metode Penelitian Pendidikan. Bandung: PT. Remaja Rosdakarya, 2011.

[10] R. Heinich, M. Molenda., Russel, D. James Smaldino, E. Sharon, Instructional Media and Technologies for Learning.( 7 thEd), New Jersey: Merill Prentice Hal, 2002.

[11] K.B. Harlig and Z. Dornyei, "Do Language Learners Recognize Pragmatic Violations? Pragmatic versus Grammatical Awareness in Instructed L2 Learning” TESOL Quarterly, 32, 2. Summer, 233-262, 1998. 